\title{
A Quantum Chemical and Chemometrical Study of Styrylbenzylsulfones and their Analogues with Citotoxic Activity against Prostate Cancer Cells
}

\author{
dos Santos, D. L.; Paula, C. B.; Carvalho-Silva, V. H.;* Camargo, A. J.; \\ Camargo, L. T. F. M.
}

Rev. Virtual Quim., 2016, 8 (2), 506-514. Data de publicação na Web: 9 de abril de 2016

http://rvq.sbq.org.br

\begin{abstract}
Um Estudo Químico Quântico e Quimiométrico da Styrylbenzylsulfones e seus Análogos com Atividade Citotóxica contra Células do Câncer de Próstata
\end{abstract}

Resumo: O câncer é um termo genérico para um grande grupo de doenças baseado no desenvolvimento rápido de células anormais que crescem além dos seus limites usuais, e que podem se espalhar para outros órgãos. Este processo é referido como metástase. O câncer de próstata é o sexto tipo de câncer mais comum em todo o mundo, a quarta principal causa de morte por câncer no Brasil. As propriedades moleculares de 34 análogos de Styrylbenzylsulfones com atividade citotóxica contra células cancerosas humanas da próstata foi calculado através do método: Teoria do Funcional de Densidade com o nível B3LYP/6-31G .Quatro descritores (ângulo diedral entre os átomos: 17, 18, 23 e 24; as ordens de ligação entre átomos de 18-19 e 20-21; e polarizabilidade) foram responsáveis pela discriminação do dois grupos de moléculas ( ativos e inativos) e para isto foi utilizado uma técnica de reconhecimento de padrão: Análise do Componente Principal ( PCA ). Este modelo foi capaz de discriminar 20 ativos de 14 inativos dos análogos usando apenas uma componente principal, sendo responsável por $51.20 \%$ da variância total e que permite melhor compreender a influência desses descritores eletrônicos na atividade citotóxica.

Palavras-chave: Styrylbenzylsulfonas; Câncer de Próstata; PCA; B3LYP.

\begin{abstract}
Cancer is a generic term for a large group of diseases related to rapid creation of abnormal cells that grow beyond their usual boundaries, and which can then spread out to other organs. This process is referred to as metastasis. Prostate cancer is the sixth most common cancer worldwide, the fourth leading cause of death from cancer in Brazil. The Density Functional Theory method at B3LYP/6-31G* was employed to calculate a set of molecular properties (variables) of 34 Styrylbenzylsulfones analogues with cytotoxic activity against human prostate cancer cells. Four descriptors (dihedral angle between atoms 17, 18, 23 and 24; bond orders between atoms 18-19 and 20-21; and polarizability ) were responsable to discriminate the two groups of molecules ( active and inactive ) and this result was used for pattern recognition method. This model was able to discriminate 20 active from 14 inactive of the analogues by using only one principal component, accounting for $51.20 \%$ of the total variance and allowing to better understand the influence of these electronic descriptors in the cytotoxic activity.
\end{abstract}

Keywords: Styrylbenzylsulfonas; Prostate Cancer; PCA; B3LYP.

\footnotetext{
* Universidade Estadual de Goiás, Unidade Universitária de Ciências Exatas e Tecnológicas, P.O. Box 459, CEP 75001-970, Anápolis-GO, Brasil..

M fatioleg@gmail.com

DOI: $10.5935 / 1984-6835.20160037$
}

Rev. Virtual Quim. |Vol 8| | No. 2| |506-514| 


\section{A Quantum Chemical and Chemometrical Study of Styrylbenzylsulfones and their Analogues with Citotoxic Activity against Prostate Cancer Cells \\ Daiane L. dos Santos, ${ }^{a}$ Camila B. Paula, ${ }^{\text {a }}$ Valter Henrique Carvalho- Silva, ${ }^{a, *}$ Ademir J. Camargo, ${ }^{a}$ Lilian T. F. M. Camargo ${ }^{b}$ \\ a Universidade Estadual de Goiás, Unidade Universitária de Ciências Exatas e Tecnológicas, P.O. Box 459, CEP 75001-970, Anápolis-GO, Brasil.

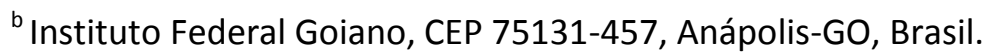 \\ * fatioleg@gmail.com}

\section{Introduction}

\section{Methodology}

\subsection{Studied data set}

2.2. Molecular descriptors

2.3. Selection of descriptors by chemometrical methods

\section{Results and Discussion}

\section{Conclusions}

\section{Introduction}

Cancer is a generic term used to more than hundred diseases whose character in common is the uncontrolled growth and spread of cells. It can affect almost any part of the body. According to the World Health Organization (WHO) more than $70 \%$ of all cancer deaths occurred in low- and middle income countries. Deaths from cancer worldwide are projected to continue rising with an estimated of 12 million deaths in $2030 .^{1-3}$

Currently, prostate cancer is the sixth most common cancer worldwide, the fourth leading cause of death from cancer in Brazil, representing about $10 \%$ of all cancer cases. In most cases, the tumor has a slow growth, long doubling time, taking about 15 years to reach $1 \mathrm{~cm}^{3}$ and affects men over 50 years of age. $^{4,5}$

The treatments used to combat prostate cancer are not effective and cause many side effects, then grows the interesting in discovering new drugs that are efficient to combat this disease. ${ }^{6-11}$ The present work investigated the relationship between the geometric and electronic properties and the activity of a group of 34 compounds of Styrylbenzylsulfones ${ }^{12}$ reported in the literature as presenting a certain degree of anti-prostate cancer ${ }^{13-16}$ by using quantum

Rev. Virtual Quim. |Vol 8| |No. 2| |506-514| 
chemistry methods to calculate molecular descriptors. Multivariate statistical methods were used to analyze and classify a data set of the molecules into groups that can be correlated to their activity.

Table 1. Molecular structure and atomic label adopted in the calculation for Styrylbenzylsulfones and their derivates analogues and activities

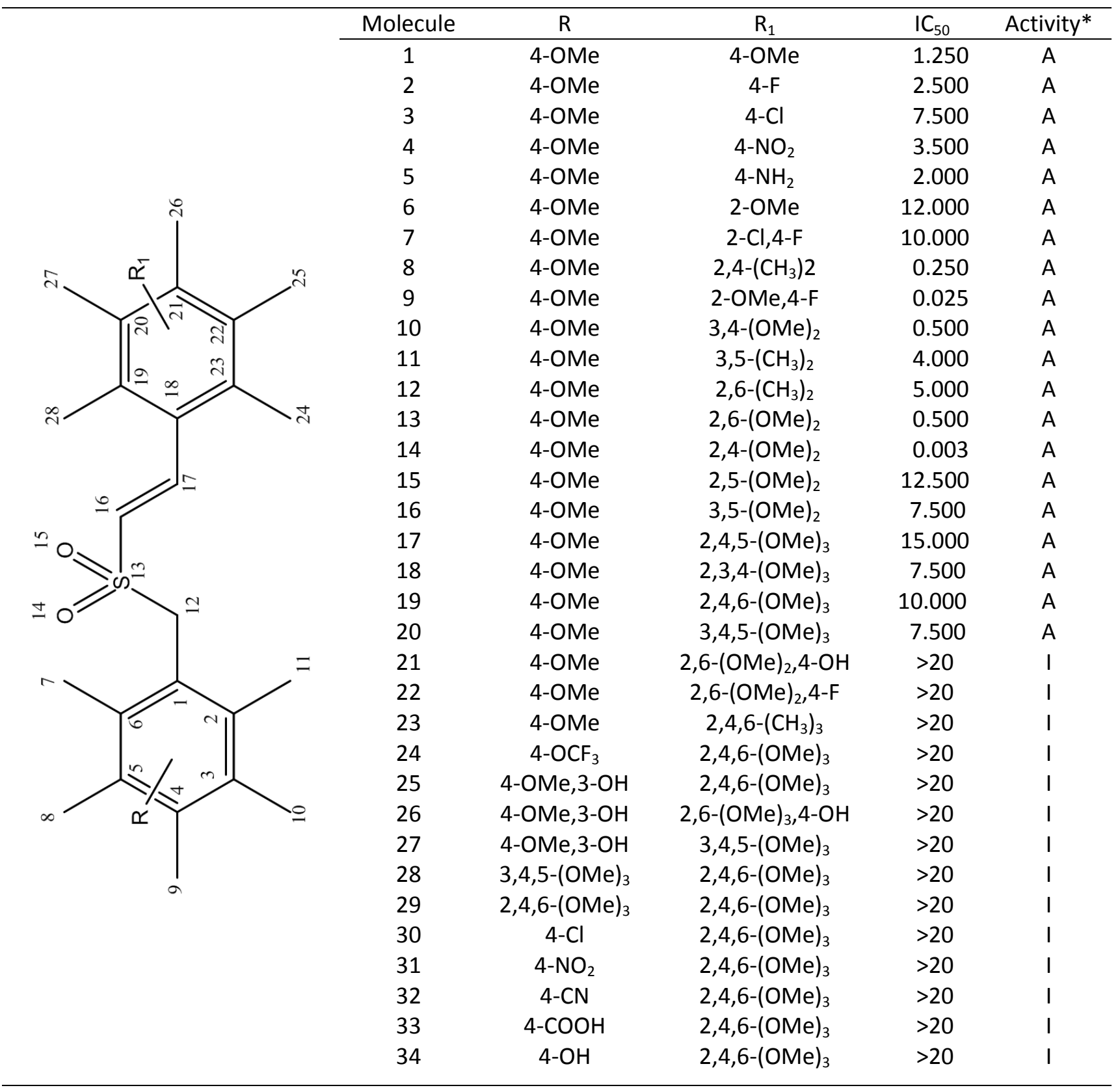

${ }^{*} A$ - Active, I - Inactive.

\section{Methodology}

\subsection{Studied data set}

The $\mathrm{IC}_{50}$ values estimated by Reddy ${ }^{13}$ were used in this work and are showed in Table 1. From 34 molecule studied, 14 compounds have been observed to be inactive against prostate cancer cell lines $\left(\mathrm{IC}_{50}>20 \mu \mathrm{M}\right)$, while the remaining compounds have been 
considered inactive.

\subsection{Molecular descriptors}

The Styrylbenzylsulfon and their derivatives analogues presents several degrees of rotation been possible attain many geometrics conformations (Table 1 ). In the absence of crystallographic structure it is necessary to carry out conformation search to obtain the conformation of lowest energy. The conformation search was carried out by semi - empirical $\mathrm{AM}^{17}$ method using the software Hyperchem 7.5. ${ }^{18}$

The conformation of lowest energy of each compounds were optimized using the Density Functional Theory (DFT) ${ }^{19}$ with the exchange-correlation functional $\mathrm{B} \mathrm{LYP}^{20}$ and the basis set functions 6-31G*, implemented in the Gaussian $\mathrm{GO9}^{21}$ suite of programs. After optimization, it was calculate geometric and electronic properties to correlate with biological activity. Among many variables that can to be used in SAR studies the following were chosen: molecular volume $(V)$, surface area $(A)$, polarizability $(\alpha)$, refractivity, partition coefficient $(\log P$ - ratio of the concentrations of a substance at two immiscible liquids in equilibrium), bond angles, dihedral angles, bond orders (obtained using NBO program, ${ }^{22}$ included in the $\mathrm{G} 09$ package of programs), partial atomic charges $\left(C_{n}\right)$ using the CHELPG (CHarge from ELectrostatic Potential using a Grid based method) scheme by Breneman and Wiberg, ${ }^{23}$ molecular dipole moment $(\mu)$, frontier molecular orbital energies ( $E_{\text {Hомо }}, E_{\text {LUMO }}$, hardness $\left(\eta=\left(E_{L U M O}-E_{\text {НОМO }}\right) / 2\right)$ and Gap. $^{15,16,24}$
2.3. Selection of descriptors by chemometrical methods

The aim of employ the PCA ${ }^{25,26}$ method is to reduce the dimensionality of data set that presents a large number of interrelated variables explaining the variance-covariance structure. The method creates new variables as linear combinations of all the initial variables so that the first new variable contains the first largest variance and the new variable contain a second largest variance.

\section{Results and Discussion}

Before applying the PCA method, each one of the variables was autoscaled. This method is very important because each variable is equally weighted and this provides a measure of the ability of a descriptor to discriminate classes of compounds. Here, we used autoscaling to unit variance. Autoscaling to unit variance refers to mean-centering followed by dividing the standard deviation: $x_{i k}^{\prime}=\left(x_{i k}-\bar{x}_{k}\right) / s_{k}$, where $x_{i k}^{\prime}$ is the variable autoscaled, $s_{k}$ is the standard deviation of variable $k, x_{i k}$ is the variable no autoscaled, and $\bar{x}_{k}$ is the mean of the variable $k$. It could be demonstrated that the variance of an autoscaled variable is equal to 1.0 .

The best separation was obtained with four variables (Table 2): D1 ( dihedral angle between : 17, 18, 23 and 24 atoms), $(\alpha)$ Polarizibility, $\mathrm{O} 1$ ( bond orders between $19 \mathrm{e}$ 20 atoms) and 02 (bond orders between 20 e 21 atoms). 
dos Santos, D. L. et al.

Table 2. The calculated descriptors that discriminate the compounds in active and inactive classes

\begin{tabular}{|c|c|c|c|c|}
\hline Molecule & $\mathrm{O} 1(\dot{\mathrm{A}})$ & $\mathrm{O} 2(\dot{\mathrm{A}})$ & D1 (Degrees) & $\alpha\left(\dot{\mathrm{A}}^{3}\right)$ \\
\hline 1 & 14.374 & 13.732 & 0.3987 & 2026.562 \\
\hline 2 & 14.478 & 13.910 & 0.3542 & 1809.053 \\
\hline 3 & 14.508 & 13.903 & 0.3920 & 1870.624 \\
\hline 4 & 14.487 & 13.824 & 0.8515 & 2014.290 \\
\hline 5 & 14.937 & 13.243 & 0.0585 & 1776.570 \\
\hline 6 & 14.327 & 14.329 & 40.952 & 1909.083 \\
\hline 7 & 14.509 & 13.827 & -40.081 & 1878.953 \\
\hline 8 & 14.460 & 13.981 & 25.551 & 1933.711 \\
\hline 9 & 13.927 & 13.775 & -0.0076 & 1893.639 \\
\hline 10 & 14.184 & 14.215 & -0.2990 & 2157.410 \\
\hline 11 & 14.115 & 14.038 & 0.2466 & 1954.102 \\
\hline 12 & 14.026 & 14.389 & -0.8080 & 1915.109 \\
\hline 13 & 13.565 & 14.419 & 24.555 & 2029.374 \\
\hline 14 & 14.796 & 13.382 & 30.616 & 2117.830 \\
\hline 15 & 13.855 & 13.496 & 35.495 & 2080.876 \\
\hline 16 & 13.944 & 13.313 & 0.2874 & 2072.179 \\
\hline 17 & 14.068 & 12.996 & 34.783 & 2277.892 \\
\hline 18 & 14.436 & 13.624 & 40.657 & 2294.245 \\
\hline 19 & 13.673 & 13.568 & 17.156 & 2286.645 \\
\hline 20 & 13.684 & 13.250 & 0.8396 & 2241.279 \\
\hline 21 & 13.592 & 13.771 & 24.144 & 2091.281 \\
\hline 22 & 13.592 & 13.851 & 11.774 & 2126.372 \\
\hline 23 & 14.046 & 14.117 & 38.518 & 2070.348 \\
\hline 24 & 13.891 & 13.557 & 30.786 & 2184.954 \\
\hline 25 & 13.649 & 13.262 & 0.6211 & 2223.211 \\
\hline 26 & 13.575 & 13.777 & 27.633 & 2123.557 \\
\hline 27 & 13.864 & 13.578 & 31.009 & 2232.668 \\
\hline 28 & 13.867 & 13.573 & 29.373 & 2465.142 \\
\hline 29 & 13.571 & 13.726 & 25.239 & 2557.978 \\
\hline 30 & 13.589 & 13.706 & 26.938 & 2189.601 \\
\hline 31 & 13.605 & 13.639 & 61.474 & 2234.276 \\
\hline 32 & 13.988 & 1,3463 & 31.121 & 2283.633 \\
\hline 33 & 13.977 & 13.476 & 29.213 & 2283.633 \\
\hline 34 & 13.961 & 14.920 & 27.844 & 2169.569 \\
\hline
\end{tabular}

The results of the PCA calculation show that the first three principal components (PC 1, PC 2 and PC 3) explain 93,03\% of the total variance in the data set (Table 3 ), as follows: PC 1: $51,20 \%$; PC2: $24,87 \%$ and PC3: $16,95 \%$. Observed that the first component ( PC 1 ) explain around $50 \%$ variance of the data set.

The Figure 1 shows that PC 1 is responsible for the discriminating between active (1 to 20) and inactive (21 to 34) compounds. The active compounds have positive scores on the first component and the inactive compounds have negative scores. The Table 4 contains the loadings of descriptors, being the polarizibility the variable of largest loading in first component (PC 1) and $\mathrm{O} 2$ the variable of largest loading in second component (PC 2). 
Table 3. Variance explained by first three principal components

\begin{tabular}{ccc}
\hline Components & Individual Percentage & Cumulative Percentage \\
\hline PC 1 & 51.20 & 51.20 \\
PC 2 & 24.87 & 76.08 \\
PC 3 & 16.95 & 93.03 \\
\hline
\end{tabular}

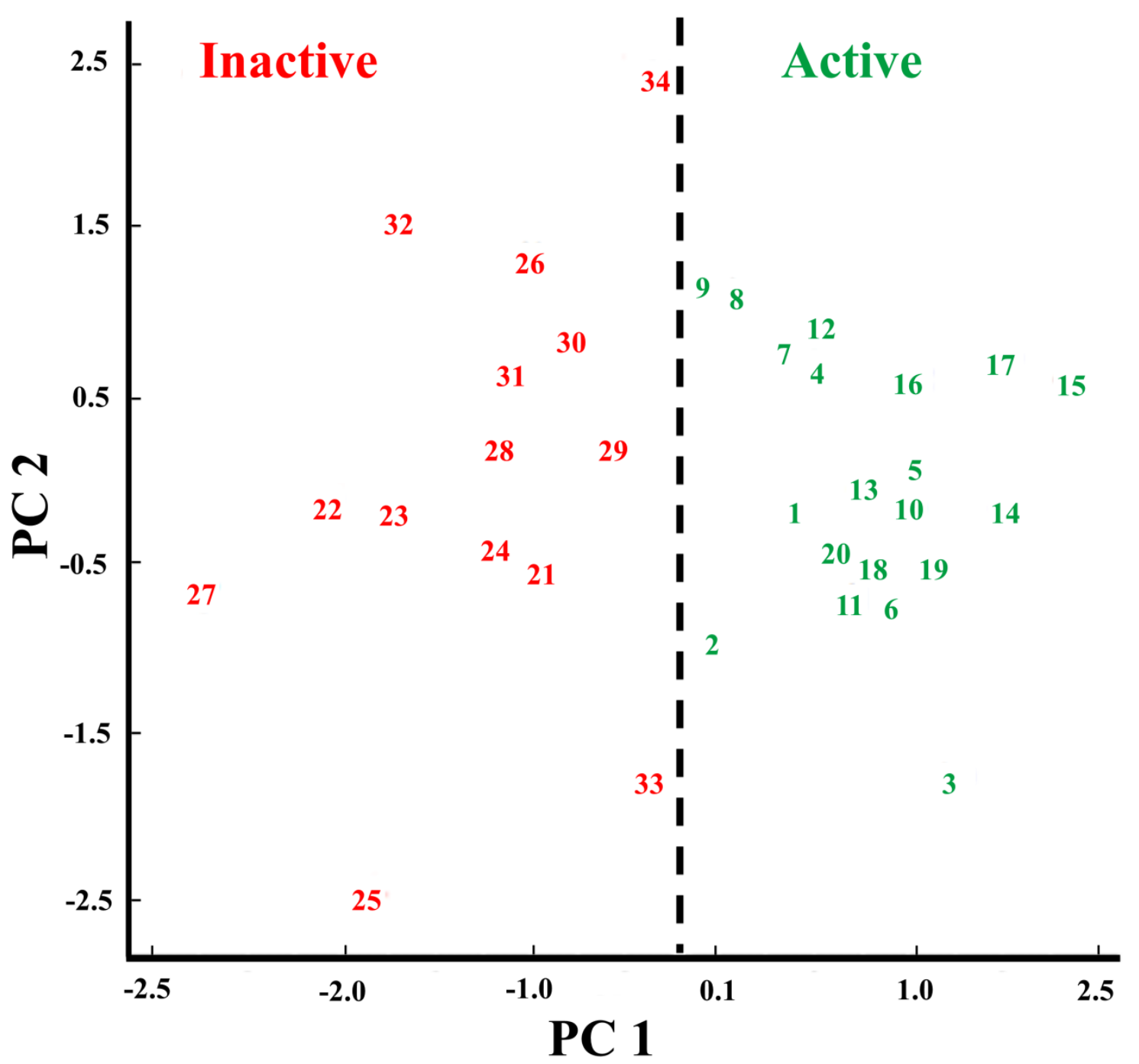

Figure 1. Graphic bmm b representation of scores

The Equation 1 presents the loading which is responsible for the discrimination values of each variable (Table 4) in the PC 1 , between active and inactive compounds.

$$
\mathrm{PC} 1=0.634(\alpha)+0.499(\mathrm{D} 1)-0.490(\mathrm{O} 1)-0.329(\mathrm{O} 2)
$$


Table 4. Loadings (weights) of the variables in the first, second and third components

\begin{tabular}{cccc}
\hline Variables & PC 1 & PC 2 & PC 3 \\
\hline$A$ & 0.634 & -0.048 & -0.152 \\
D1 & 0.499 & 0.113 & 0.823 \\
O1 & -0.490 & -0.516 & 0.512 \\
O2 & -0.329 & 0.848 & 0.193 \\
\hline
\end{tabular}

It is worth noting that the variables responsible for the separation of the compounds are electronic descriptors and geometrical descritors, suggesting that both properties are important to understand the Styrylbenzy/sulfones activity against prostate cancer.

From Equation 1 we can see that more active molecules can be obtained when we have higher values for $\mathrm{D} 1$ and $\alpha$, with small values for the bond order between $\mathrm{O} 1$ e $\mathrm{O} 2$ atoms. This can also be done by analyzing the Table 4, where: $D_{1}$ and $\alpha$ variables are the positive side of loading (as well as the active molecules), and the variables: $\mathrm{O}_{1}$ and $\mathrm{O}_{2}$ are the negative side of the graph loading (as well as the inactive molecules).

Dihedral angles are very important parameters for the study of structure activity relationship of a molecule. They vary with the exchange of substituent directly influencing the geometry of this molecule and, consequently, interfering with the drugreceptor activity. Higher values for D1 is important to molecules to be active ( Figure $1)$, this indicates the compound has a great probability of fit with the biological receptor. $^{27}$

Regarding the bond order descriptor we can define it as half of the difference among electrons in bonding and anti-bonding molecular orbital. As increasing the bond order, increasing the dissociation energy and decreasing the bond length. For the active compounds we can suggest that in positions between atoms $19-20(\mathrm{O} 1)$ and $20-21(\mathrm{O} 2)$ should presents low values electronic density and consequently, a low bond order.
According to the above results, we can postulate that increasing the values of the $D_{1}$ and $\alpha$ and decreasing the values of the $\mathrm{O}_{1}$ and $\mathrm{O}_{2}$ variables, increase the probability for the Styrylbenzylsulfones and its analogues to become active. These features can be useful in the design of new Styrylbenzylsulfones analogues with activity against prostate cancer.

\section{Conclusions}

Principal component analysis (PCA) showed that the 34 Styrylbenzylsulfones compounds studied can be classified into two groups: active and inactive according to prostate cancer activity. The D1, $\alpha, 01$ and $\mathrm{O} 2$ are responsible for the separation between active and inactive molecules and it is interesting to notice that these variables represent two distinct classes of interactions between the compounds and the biological receptor: electronic ( $\alpha, 01$ and $\mathrm{O} 2)$ and conformational (D1) interactions. The behavior of these variables can be useful when one is trying to obtain compounds with activity against prostate cancer.

\section{Acknowledgement}

The authors would like to acknowledge the Pró-Reitora de Pesquisa e Pós Graduação (PrP) of the Universidade Estadual de Goiás (UEG) for financial support for this research. 


\section{References}

${ }^{1}$ WHO | New guide on palliative care services for people living with advanced cancer. Disponivel em: $<$ http://www.who.int/mediacentre/news/not es/2007/np31/en/>. Acesso em: 6 novembro 2014.

${ }^{2}$ Are, C.; Rajaram, S.; Are, M.; Raj, H.; Anderson, B. O.; Chaluvarya Swamy, R.; Vijayakumar, M.; Song, T.; Pandey, M.; Edney, J. A.; et al. A Review of Global Cancer Burden: Trends, Challenges, Strategies, and a Role for Surgeons. Journal of Surgical Oncology 2013, 107, 221. [CrossRef] [PubMed]

${ }^{3}$ Adams, J. The Development of Proteasome Inhibitors as Anticancer Drugs. Cancer Cell 2004, 5, 417. [CrossRef]

${ }^{4}$ Portal - Instituto Nacional de Câncer - INCA Disponível em: $<$ http://www2.inca.gov.br/wps/wcm/connect inca/portal/home >. Acesso em: 6 novembro 2014.

${ }^{5}$ Heidenreich, A.; Bellmunt, J.; Bolla, M.; Joniau, S.; Mason, M.; Matveev, V.; Mottet, N.; Schmid, H.-P.; van der Kwast, T.; Wiegel, T.; Zattoni, F. EAU Guidelines on Prostate Cancer. Part 1: Screening, Diagnosis, and Treatment of Clinically Localised Disease. European Urology 2011, 59, 61. [CrossRef] [PubMed]

${ }^{6}$ Médicos, Brasil. Ministério Da Saúde; Câncer Fundamentos; Secretaria de Assistência Médica-Divisão Nacional de Câncer: Brasília, 2006; pp. 345-357.

${ }^{7}$ Temmink, O. H.; Prins, H.-J.; van Gelderop, E.; Peters, G. J. The Hollow Fibre Assay as a Model for in Vivo Pharmacodynamics of Fluoropyrimidines in Colon Cancer Cells. British Journal of Cancer 2007, 96, 61. [CrossRef] [PubMed]

${ }^{8}$ Wang, A. Z.; Langer, R.; Farokhzad, O. C. Nanoparticle Delivery of Cancer Drugs. Annual Review of Medicine 2012, 63, 185. [CrossRef] [PubMed]
${ }^{9}$ Mans, D. R. A. Anti-Cancer Drug Discovery and Development in Brazil: Targeted Plant Collection as a Rational Strategy to Acquire Candidate Anti-Cancer Compounds. Oncologist 2000, 5, 185. [CrossRef] [PubMed]

${ }^{10}$ Lu, M.; Merali, S.; Gordon, R.; Jiang, J.; Li, Y.; Mandeli, J.; Duan, X.; Fallon, J.; Holland, J. F. Prevention of Doxorubicin Cardiopathic Changes by a Benzyl Styryl Sulfone in Mice. Genes Cancer 2011, 2, 985. [CrossRef] [PubMed]

${ }^{11}$ Reddy, M. V. R.; Venkatapuram, P.; Mallireddigari, M. R.; Pallela, V. R.; Cosenza, S. C.; Robell, K. A.; Akula, B.; Hoffman, B. S.; Reddy, E. P. Discovery of a Clinical Stage Multi-Kinase Inhibitor Sodium (E)-2-2Methoxy-5-[(2', $4^{\prime}, 6^{\prime}-$

Trimethoxystyrylsulfonyl)methyl]phenylamin o Acetate (ON 01910.Na): Synthesis, Structure-Activity Relationship, and Biological Activity. Journal of Medicinal Chemistry 2011, 54, 6254. [CrossRef] [PubMed]

${ }^{12}$ Prasad, A.; Park, I.-W.; Allen, H.; Zhang, X.; Reddy, M. V. R.; Boominathan, R.; Reddy, E. P.; Groopman, J. E. Styryl Sulfonyl Compounds Inhibit Translation of Cyclin D1 in Mantle Cell Lymphoma Cells. Oncogene 2009, 28, 1518. [CrossRef] [PubMed]

${ }^{13}$ Reddy, M. V. R.; Mallireddigari, M. R.; Cosenza, S. C.; Pallela, V. R.; Iqbal, N. M.; Robell, K. A.; Kang, A. D.; Reddy, E. P. Design, Synthesis, and Biological Evaluation of (E)Styrylbenzylsulfones as Novel Anticancer Agents. Journal of Medicinal Chemistry 2008, 51, 86. [CrossRef] [PubMed]

${ }^{14}$ Karelson, M.; Lobanov, V. S.; Katritzky, A. R. Quantum-Chemical Descriptors in QSAR/QSPR Studies. Chemical Reviews 1996, 96, 1027. [CrossRef] [PubMed]

${ }^{15}$ Martins, G. R.; Napolitano, H. B.; Camargo, L. T. F. M.; Camargo, A. J. Structure-Activity Relationship Study of Rutaecarpine Analogous Active against Central Nervous System Cancer. Journal of the Brazilian Chemical Society 2012, 23, 2183. [CrossRef]

${ }^{16}$ Camargo, L. T. F. M.; Sena, M. M.; Camargo, A. J. A Quantum Chemical and 
Chemometrical Study of indolo[2,1B]quinazoline and Their Analogues with Cytotoxic Activity against Breast Cancer Cells. $S A R$ and QSAR in Environmental Research 2009, 20, 537. [CrossRef] [PubMed]

${ }^{17}$ Dewar, M. J. S.; Jie, C.; Zoebisch, E. G. AM1 Calculations for Compounds Containing Boron. Organometallics 1988, 7, 513. [CrossRef]

${ }^{18}$ HyperChem, Release 7.0, Hypercube Inc.; Gainesvile, FL 32601, USA.

${ }^{19}$ Parr, R. G.; Yang, W.; Density Functional Theory of Atoms and Molecules, Oxford: New York, 1989.

${ }^{20}$ Becke, A. D. Density-Functional ExchangeEnergy Approximation with Correct Asymptotic Behavior. Physical Review A 1988, 38, 3098. [CrossRef] [PubMed]

${ }^{21}$ Frisch, M. J.; Trucks, G. W.; Schlegel, H. B.; Scuseria, G. E.; Robb, M. A.; Cheeseman, J. R.; Scalmani, G.; Barone, V.; Mennucci, B.; Petersson, G. A.; Nakatsuji, H.; Caricato, M.; Li, X.; Hratchian, H. P.; Izmaylov, A. F.; Bloino, J.; Zheng, G.; Sonnenberg, J. L.; Hada, M.; Ehara, M.; Toyota, K.; Fukuda, R.; Hasegawa, J.; Ishida, M.; Nakajima, T.; Honda, Y.; Kitao, O.; Nakai, H.; Vreven, T.; Montgomery, J. A., Jr.; Peralta, J. E.; Ogliaro, F.; Bearpark, M.; Heyd, J. J.; Brothers, E.; Kudin, K. N.; Staroverov, V. N.; Kobayashi, R.; Normand, J.; Raghavachari, K.; Rendell, A.; Burant, J. C.; lyengar, S. S.; Tomasi, J.; Cossi, M.; Rega, N.; Millam, J. M.; Klene, M.; Knox, J. E.; Cross, J. B.; Bakken, V.; Adamo, C.; Jaramillo, J.; Gomperts, R.; Stratmann, R. E.; Yazyev, O.; Austin, A. J.; Cammi, R.; Pomelli, C.; Ochterski, J. W.; Martin, R. L.; Morokuma, K.;
Zakrzewski, V. G.; Voth, G. A.; Salvador, P.; Dannenberg, J. J.; Dapprich, S.; Daniels, A. D.; Farkas, Ö.; Foresman, J. B.; Ortiz, J. V.; Cioslowski, J.; Fox, D. J. Gaussian 09 Revision D.01, 2009.

${ }^{22}$ Weinhold, F.; Landis, C. R. Natural Bond Orbital and Extensions of Localized Bonding Concepts. Chemistry Education Research and Practice 2001, 2, 91. [CrossRef]

${ }^{23}$ Breneman, C. M.; Wiberg, K. B. Determining Atom-Centered Monopoles from Molecular Electrostatic Potentials. The Need for High Sampling Density in Formamide Conformational Analysis. Journal of Computational Chemistry 1990, 11, 361. [CrossRef]

${ }^{24}$ Lameira, J.; Medeiros, I. G.; Reis, M.; Santos, A. S.; Alves, C. N. Structure-Activity Relationship Study of Flavone Compounds with Anti-HIV-1 Integrase Activity: A Density Functional Theory Study. Bioorganic \& Medicinal Chemistry 2006, 14, 7105. [CrossRef] [PubMed]

${ }^{25}$ Sharaf, M. A.; Illman, D. L.; Kowalski, B. R.; Chemometrics, A Wiley-Interscience publication, 1986. [PubMed]

${ }^{26}$ Brereton, R. G. Introduction to Multivariate Calibration in Analytical Chemistry. Analyst 2000, 125, 2125. [CrossRef]

${ }^{27}$ Kubinyi, H.; Mannhold, R.; KrogsgaardLarsen, P.; Timmerman, H.; QSAR: Hansch Analysis and Related Approaches; Methods and Principles in Medicinal Chemistry, Wiley, 2008. 